\title{
経皮的腎尿管結石破砕除去術の検討
}

\begin{tabular}{|c|c|c|c|c|c|c|c|}
\hline 大島 & 伸一 & 絹川 & 常郎 & 松浦 & 治 & 竹内 & 宣久 \\
\hline 服部 & 良平 & 長谷) & 川総一郎 & 小野 & 佳成 ${ }^{1)}$ & 平林 & 聡1) \\
\hline 山田 & 伸 ${ }^{1)}$ & 藤田 & 民夫²) & 松井 & 基治 ${ }^{2)}$ & & \\
\hline
\end{tabular}

\section{PERCUTANEOUS NEPHROLITHOTRIPSY}

Shinichi Ohshima, Tsuneo Kinukawa, Osamu Matsuura, Norihisa Takeuchi, Ryohei Hattori, Soichiro Hasegawa, Yoshinari Ono*, Satoshi Hirabayashi*, Shin Yamada*,

Tamio Fujita** and Motoharu Matsui**

Department of Urology, Shakai Hoken Chukyo Hospital

*Department of Urology, Komaki City Hospital

**Department of Urology, Nagoya Memorial Hospital

The results of 272 patients who underwent percutaneous removal of renal and ureteral stones were presented. The stones were completely removed in 199 kidneys or ureters $(70.8 \%)$, incompletely removed in $66(23.5 \%)$ and could not removed in $16(5.7 \%)$. The residual rate was $81.8 \%$ in complicated staghorn calculi, $33.3 \%$ in staghorn calculi, $48.2 \%$ in multiple calculi, $8.6 \%$ in simple calculus and $16.6 \%$ in ureteral calculus.

Major complications consisted of arteriovenous fistula (1 patient), pseudoaneurysma (1 patient), complete obstruction of ureteropelvic juncion ( 1 patient), sepsis ( 1 patient) and massive bleeding requiring more than $1000 \mathrm{ml}$ blood transfusion (13 patients). Two patients with vascular complications were managed by angiography with embolizations and the patient with ureteral damage had a reconstructive surgery ureterocalicostomy. The patient with sepsis was managed by appropriate antibiotic treatment.

The rate of residual calculi and major complications in this procedure were higher than that in the open surgery. There were some difficulties in completely removing complicated staghorn calculi and multiple calculi through this procedure. The indication of this procedure was discussed.

要旨：経皮的腎尿管結石破砕除去術を施行した272例281腎・尿管の成績を報告し，腎尿管結石に対する 本術式の現時点の適応について私見を述べた。

199腎・尿管（70.8\%）で結石の完全除去が，66腎・尿管（23.5\%）で残石がみられ，16腎・尿管では 結石除去が不可能であった。 結石の形態からみた残石率（残石例十結石除去不能例）は, 複雑删瑚状結 石 $81.8 \%$, 删瑚状結石 $33.3 \%$, 多発結石 $48.2 \%$, 単発結石 $8.6 \%$ であり, 尿管結石では $16.6 \%$ あった。 招もな合併症では，1例に腎動静脈瘻，1例に仮性動脈瘤，1例に腎孟尿管移行部完全閉塞，1例に 敗血症, 13例に $1,000 \mathrm{ml}$ 以上の輸血を必要とした出血がみられた. 腎動静脈瘦及び仮性動脈瘤は経皮的塞 栓術にて, 腎孟尿管移行部閉塞は尿路再建手術にて, また, 敗血症に対しては抗生剂投与による治療に て改善をみた。

1.はじめ $1 に$

近年, 腎結石症に対する腎保存手術として open surgeryにかわって percutaneous nephrolithotripsy（以 下 PNL) がひろく行われるようになった闹。 しかし
ながら，PNLの普及にともない，PNLのもついくつ かの問題点が議論されるよらになってきた.すなわち, 多発結石や删瑚状及び複雑珊瑚状結石症例での高頻度 の残石, 腎瘦造設・結石破砕除去から生ずる腎, 腎盂 
尿管の損傷等である，今回，腎結石症に対する腎保存 手術としての本術式の問題点と限界を明らかにする目 的で，私共の経験について報告し，若干の検討を加光 報告する。

\section{2. 対 象}

対象は, 1979年12月から社会保険中京病院泌尿器科, 小牧市民病院泌尿器科, 名古屋記念病院泌尿器科で本 術式を施行した腎結石症例272例281腎である。患者の 年齢は14歳から77歳, 平均士S.D. $45.8 \pm 14.5$ 歳, 男性 182例，女性90例である。手術腎の結石形態は既に私共 が報告した分類に従い ${ }^{8)}$, 複雑珊瑚, 珊瑚状, 多発, 単 発腎結石及び尿管結石に分類した。それぞれ 22 腎 (7.8\%)，9腎(3.2\%)，86腎(30.5\%)，93腎(33.0\%) 及び72腎（72尿管）（25.5\%）であった。

\section{3. 方 法}

\section{手術方法}

腎瘻造設は，手術に先立って直前あるいは手術前 3 〜 7 日に施行した。腎瘦は経皮的に局所麻酔あるいは 硬膜外麻酔下に Amplatz dilator (Cook 社製)，金属 dilator（Wolf 社製）を用いて22Fr 腎孟カテーテルを 留置し作製した。手術は硬膜外麻酔あるいは気管内插 管による全身麻酔下に，腎瘦より腎孟鏡（Wolf 社製） を捙入乙, 超音波, 電気水圧衝撃波 (以下衝撃波) に て結石を破研，除去した。また，破碎片と鉗子にて摘 出除去した。な拉, 破砕片が尿管へ嵌入するのを防止 する目的で術前に double J catheter 7 9Fr 尿管力 テーテル，尿管閉塞用バルーン付カテーテルを留置し た症例もある。潅流液は生理食塩水を用い, $60 \sim 100 \mathrm{~cm}$ の高さより自然圧で潅流した. 手術終了時に $22 \mathrm{Fr}$ 腎孟 カテーテルを留置した。手術後 4 〜 日で腎孟造影を 施行し, 残石の有無, 腎孟損傷の有無を検索し, 腎孟 カテーテルを抜去した。

\section{検查項目}

以下の項目について検索, 検討した.

1）腎瘻造設数, 腎瘦造設時期

2) 結石除去手術回数

3）結石除去方法

4）結石除去率

5）結石形態と結石除去率

6）失敗例の原因と予後

7) 合併症

\section{4. 結 果}

1）造設腎瘻数と腎瘦造設時期

失敗例を除く265腎のうち, 1 力所の腎瘻より結石を
破砕除去したものは，254腎 (95.8\%)，2 カ所以上の 腎瘻より施行したものは11腎 $(4.2 \%)$ であった。

腎瘦造設時期については, 結石除去手術の直前に腎 瘦造設を行った one stage 法は48腎 (18.1\%) に行い, 他の 207 腎 $(81.9 \%)$ では, 結石除去手術の数日前に腎 瘦造設を行う two stage 法で行った。

2) 結石破砕除去手術回数

結石破砕除去手術は265腎に332回施行した。 1 回の 手術で終了したもの 212 腎 (80.0\%)，2 回の手術を施 行したもの 44 腎(16.6\%), 3 回の手術を施行したもの 8 腎(3.0\%)， 4 回の手術を施行したもの 2 腎 $(0.8 \%)$ であった。

3）結石除去方法

332回の手術に抢ける結石の破砕除去方法は, 鉗子除 去55回 (16.6\%), 超音波破砕除去156回 (47.0\%), 超 音波破研除去十鉗子摘出76回 (22.9\%), 衝撃波破砕十 鉗子摘出13回 (3.9\%), 超音波破砕十衝撃波破挽27回 (8.1\%), 衝撃波破砝十超音波破砕除去十鉗子摘出 5 回 （1.5\%）であった.

\section{4）結石除去率}

199腎（70.8\%）で結石の完全除去が可能であった。 66腎（23.5\%）では，残石あるいは結石片が尿路外へ 逸脱した尿路外結石が生じ, 不完全摘出に終った 16 腎 （5.7\%）では，結石は全く摘出できなかった。 5ち， 腎瘻造設に失敗したものは 9 腎 $(3.2 \%)$, 腎㿉は造設 したものの結石の摘出が不可能であったものは 7 腎 （2.5\%）であった。な技，残石率＝失敗率十不完全摘 出率は $29.2 \%$ であった。

5）結石の形態と結石除去率

結石の形態別の結石除去率は表 1 に示した。各結石 形での残石率 $=$ 失敗率十不完全摘出率は, 複雑珊瑚状 結石で $81.8 \%$ と最も高く，次いで多発結石が $48.2 \%$ と 删瑚状結石が $33.3 \%$ であった。尿管結石で $16.6 \%$, 単 発結石で $8.6 \%$ であった.

6）失敗例の原因とその予後

16腎でPNLによる結石の除去が不可能であった が，その原因は，腎瘻造設不能 5 腎，腎瘻造設時に出 血により造設を中止したもの 3 腎, 腎瘻造設時に腎孟

表 1 結石型と結果

\begin{tabular}{lrlrr} 
& 例数 & 失敗 & \multicolumn{1}{c}{ 不完全摘出 } & \multicolumn{1}{c}{ 完全摘出 } \\
複椎㑚栵状結石 & 22 & $0(0 \%)$ & $18(81.8 \%)$ & $4(18.2 \%)$ \\
㑚瑚状結石 & 9 & $0(0 \%)$ & $3(33.3 \%)$ & $6(66.7 \%)$ \\
多発結石 & 85 & $8(9.4 \%)$ & $33(38.8 \%)$ & $44(51.8 \%)$ \\
単発結石 & 93 & $1(1.1 \%)$ & $7(7.5 \%)$ & $85(91.4 \%)$ \\
尿管結石 & 72 & $7(9.7 \%)$ & $5(6.9 \%)$ & $60(83.3 \%)$
\end{tabular}


表 2 失敗例の原因と予後

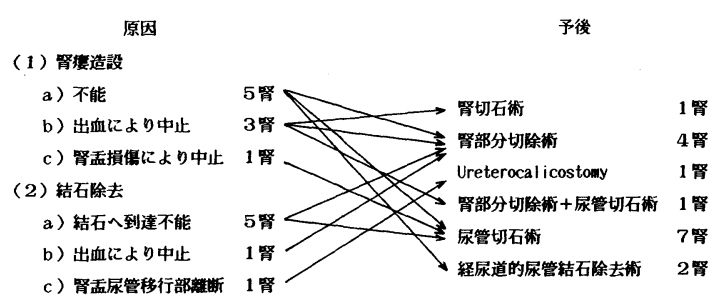

損傷を合併し中止したもの 1 腎, 腎瘻は造設可能で あったものの結石に到達不可能であったもの 5 腎, 出 血により結石の破砕除去が不可能であったもの 1 腎,

腎孟損傷から腎孟尿管離断により結石の破砕除去が不 可能であった 1 腎である. 4 腎は腎部分切除術， 7 腎 は尿管切石術， 2 腎は経尿道的尿道結石除去術，1腎 はUreterocalicostomy，1腎は腎切石術，1腎では腎 部分切除術と尿管切石術を施行した（表 2 ）.

7) 合併症

輸血を要した腎瘻造設あるいは, 結石破砕時の出血 は35腎 $(12.5 \%)$ にられ，らち13腎 (4.6\%) は1,000 $\mathrm{ml}$ 以上の輸血を要した。 らち， 2 腎 $(0.7 \%)$ で止血, 結石除去を目的として腎部分切除術を施行した。1腎 に動静脈瘻， 1 腎に動脈瘤がみられ，それぞれ術後出 血を繰り返していたため経腎動脈的にスチール・コイ ルを用い，腎動脈枝を閉塞させ治癒せしめた。他はす べて保存的治療にて止血した。

腎孟・尿管の損傷は，11腎（3.9\%）にみられた。 ち， 1 腎 $(0.4 \%)$ は前述した症例で腎孟尿管移行部で の結石を採取時に損傷を起こし術後 7 日目に腎孟造影 にて同部の完全閉塞がみられUreterocalicostomyを 必要とし，2腎 (0.7\%) では結石破砕除去中に腎盄穿 孔を合併し, 術中に後腹膜・腹腔内一の大量の潅流液 の漏出を認め, 結石除去直後に腹腔内ドレナージを施 行した。 1 腎 (0.4\%) では腎孟に穿孔を認めたため本 術式を中止し，open surgeryにて結石を除去した。 7 腎 (2.5\%) では結石破砕除去中に尿管に損傷を生じた ため, 結石除去後尿管に stent catheter を留置した。

これら 7 例は全て術後狭窄を残すことなく経過してい る。また，腎盘，腎杯，尿管外に結石片が逸脱した尿 路外結石が19腎 (6.8\%) に認められた。術後, 敗血症 を合併したものは 1 例で結石除去後腎盂カテーテルが 留置できず，尿瘦を合併し，術前からあった尿路感染 と相まって septic shock に陥った。尿瘻は 3 術後日に は消失し，保存的治療にて治癒した。

\section{5. 考案}

PNL が尿路結石, 主に腎結石の治療に革命的変化を 起こしたこと执よび，その優れた価値について述べる ことには多くの論を要しない。本治療法の最大の価値 は, いわゆる open surgery を必要とせず, 従って, 体 表面に切開創が残らない点にある，現時点では本治療 法は普及の一途を進んでいるといっても過言ではな い、しかし，今回の検討でも見られた，(1)多発，珊瑚 状, 複雑删瑚状結石での高頻度の残石, (2)腎瘻造設, 結石破砕時の出血, また, (3)腎, 腎孟, 尿管などの損 傷などいくつかの問題を内蔵しており, 今後, それら の問題が, 何等かの形で解決されない限り, PNLの限 界として示される可能性があると考える.

結石の治療の主流が open surgeryであった時代に は手術による侵襲が出来るだけ小さく, 腎への障害が 極力少ない方法で, 全ての結石を完全に摘出すること の出来る術式が理想とされてきたが9), この立場から PNL と open surgery とを比較してみると PNLが優 れているのは手術侵襲の面であり, 腎への障害につい ては, 腎盘切除術よりも劣って抢り, 腎切石術とでは どちらとも判定できない(910). 残石についてみてみる と私共の今回の経験では PNL の方が残石率が高く, 特に多発・删瑚状・複雑珊瑚状結石などの複雑な結石 ではそれぞれ $48.2 \% ， 33.3 \% ， 81.8 \%$ と著しい。これ は open surgeryによる残石率について報告した私共 の成績に比べても悪く ${ }^{11)}$, 結石の完全摘出といら面で は, open surgeryよりも劣るという結果であった。 た, 今回の私共の成績と他の報告を比べてみると, 私 共の成績は決して満足のいくものではない。これにつ いては無論，私共の技術的未熟さについての反省も指 摘されねばならぬが，残石といら概念にいささかの混 乱があることも指摘して括く必要がある。 open surgery と異なり, 術前から全ての結石の摘出は不可能で あるといら判断で治療にかかる症例もあり得るかと思 われるが，その様な場合に targeted stone や成功率之

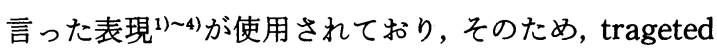
stone 以外の結石についての消長が不明である。私共 は open surgery の場合と同じょうに先に述べた基準 で残石を決め報告したが，この点で他の報告者のもの と意味が異なっているかと思われる. 複雑な結石での 完全摘出をPNLで行うとすれば, 腎の構造の複雑多 様性から 1 カ所の腎瘦では不可能であり, 場合によっ ては数カ所の腎瘻の設置が必要である. 数力所の腎瘻 の設置が, 腎への障害といら観点からどの様に評価さ 
れるべきかは，今後の問題であるが，造設腎瘦数が多 くなればなるほど，腎機能の保存といら面から望まし くないことだけは確かである。体外衝撃波による結石 破砕（以下 ESWL）の併用が複雑な結石例での残石の 問題に対して一定の効果を生むことが最近報告されて おり ${ }^{121313}$, ESWLの欠点を補らという意味でも今後更 に検討すべき方法であろう。また，PNLに使用する内 視鏡や結石破碎装置, 摘出機器等々の工夫や改善が現 在の水準をどこまで超えることが出来るかも今後の発 展進歩を考える上で重要な点であろう。

今回の検討では PNLによる致命的合併症はなかっ たが，大量出血や腎内動静脈瘻，動脈瘤，腎孟尿管の 完全閉塞など簡単に看過することのできぬ合併症がみ られた. endourologyの場合，技術の巧拙や慣れが， こらした合併症の発生に大きく関与する要素であるこ とを考慮にいれても，281腎中14例という頻度は高い。 限られた視野の内で術者 1 人による操作といら条件下 での各個人の技術の向上が，この種の合併症の発症を ぞこまで少なくできるかが今後の課題であり，その後 に, この面からの PNLの限界も明らかにされてくる であろら。

私共の PNLの経験をそれ以前に行っていた open surgery と比較しながら検討してみたが, 現時点では, 先に述べたように PNLが術者の技量に左右されやす いといら点から, PNL の評価をするにはをだ早いと言 らのが結論である. 問題点を以下にまとめると，(1)残 石率は高い. (2)ある種の複雑な結石では, PNLでは完 全な摘出は不可能である. (3)合併症の頻度は open surgery に比し高い, (4)腎瘻を置く操作が腎に与える影響 については不明である。等々が挙げられる，今後これ らの問題に対する解決の方向性については, 次のょう に考学る. (1)各術者の向上, (2)機器の工夫・改善, (3) ESWL との併用療法の導入, 当面はこれらの方向で成 績の向上に努力すべきである，その後にPNLによる 腎結石治療の利点と限界が明らかになり，その時点で 適応も明らかにされ，あるいは open surgery の再評価 と新たな適応の決定といら問題が起こってくる可能性 もあろう。

\section{文献}

1) Segura, J.W., Patterson, D.E., LeRoy, A.J., Williams, H.J., Barrett, D.M. Jr. and Benson, R. C. Jr.: percutaneous removal of kidney stones: Review of 1000 cases. J. Urol., 134,
1077-1083, 1985.

2) Alken, P., Hutschenreiter, G., Gunther, R. and Marberger, M. : Percutaneous stone manipulation. J. Urol., 125, 463-466, 1981.

3）棚橋善克, 千葉 裕, 桑原正明, 沼田 功, 豊田精 一, 黒須清一, 前原郁夫, 田口勝行, 折笠精一：経 皮的腎尿管結石摘出術(第 2 報)。 日泌尿会誌, 76, 1314-1322, 1985.

4）川村寿一, 上田 真, 野々村光生, 西村一男, 西尾 恭規，飛田収一，大石賢二，東 義人，岡田裕作， 竹内秀雄，吉田 修: 最近 1 年間に打ける上皮尿 路結石症に対する経皮的破砕摘出の成績（経尿道 的操作を含む). 泌尿紀要, 31, 2183-2192, 1985.

5）西村泰呈, 坪井成美, 秋元成太：経皮的腎尿管切石 術. 第 9 報。鉗子操作を中心に. 日泌尿会誌, 77 , $1-4,1986$.

6）松岡 啓, 植田省吾, 吉武信行, 国見 宏, 村上雅 己, 中川克之, 宮原 茂, 野田進士, 江藤耕作：経 皮的腎尿管結石摘出術100例の経験. 西日泌尿会 誌，48，1599-1604，1986。

7）松浦 健, 加藤良成, 朴 英哲, 光林 茂, 神田英 憲, 金子茂男, 秋山隆弘, 栗田 孝：経皮的腎尿管 結石破砕術．日泌尿会誌，78，484-488，1987.

8）小野佳成, 梅田俊一, 絹川常郎, 松浦 治, 平林 聡, 小川洋史, 竹内宣久, 大島伸一, 三矢英輔：腎 結石に対する腎保存手術の検討，泌尿紀要，27， 135-140, 1981.

9）小野佳成, 大島伸一, 絹川常郎, 松浦 治, 竹内宣 久, 服部良平：単腎症例に打ける珊瑚状結石に対 する腎保存手術について。泌尿紀要, 31 , 1407-1411, 1985.

10) Ekelund, L., Lindstedt, E., Lundquist, S.B., Sundin, T. and White, T.: Studies on renal damage from percutaneous nephrolitholapaxy. J. Urol., 135, 682-685, 1986.

11）小野佳成, 絹川常郎, 松浦 治, 平林 聡, 竹内宣 久, 服部良平, 大島伸一：腎結石に対する腎保存手 術の検討一その2-. 泌尿紀要, 31, 579-583, 1985.

12) Kahnoski, R.J., Lingeman, J.E., Coury, T.A., Steele, R.E. and Mosbaugh, D.J.: Combines percutaneous and extracorporeal shock wave lithoripsy for staghorn calculi: Alternative to anatrophic nephrolithotomy. J. Urol., 135, 679-681, 1985.

13) Schulze, H., Hertle, L., Graff, J., Funke,P.J. and Senger, T.: Combined treatment of branched calculi by percutaneous nephrolithotomy and extracorporeal shock wave lithotripsy. J. Urol., 135, 1138-1141, 1986.

（1987年12月 1 受理） 